\title{
An intergenerational transmission of sustainability? Ancestral habitus and food production in a traditional agro-ecosystem of the Upper Guinea Forest, West Africa
}

\author{
James Angus Fraser*, Victoria Frausin, Andrew Jarvis \\ Lancaster Environment Centre, Lancaster University, Lancaster LA1 4YQ United Kingdom
}

\section{A R T I C L E I N F O}

\section{Article history:}

Received 15 June 2014

Received in revised form 12 January 2015

Accepted 19 January 2015

Available online

\section{Keywords:}

Traditional agro-ecosystems

Indigenous knowledge

Anthropogenic dark earths

Sustainable development

Ancestor worship

\begin{abstract}
A B S T R A C T
The need for sustainable alternatives to industrial farming has led to a revival of interest in traditional agro-ecosystems. Whilst it is well recognised that traditional agro-ecosystems are both social and physical-technical - few case studies have examined interactions between both these dimensions in a single system. For a system to be considered sustainable it needs to be shown to have retained key characteristics over several generations. Case studies therefore demand a location where intergenerational transmission of agro-ecological knowledge and practice is ongoing. This paper examines the intergenerational transmission of social and physical-technical dimensions of a traditional agroecosystem of the Loma people in NW Liberia. We engage an innovative interdisciplinary combination of methodologies in analyzing interactions between: (i) energy efficiencies (yield to labour) in 3 different Loma food production systems, using longitudinal quantitative surveys, and, (ii) the social institutions that mediate food production practice, using qualitative methods. Our energy efficiency calculations show that AfDE cultivation is more than twice as efficient at producing calories as either shifting cultivation or forest and river extractivism, yet GPS mapping demonstrates that AfDE cultivation is highly spatially restricted despite clear opportunities for expansion and optimisation. This raises an important question: why have the Loma not expanded AfDE cultivation? We propose that despite being fully aware of the opportunities AfDEs present, a Loma 'ancestral habitus' and substantive economic rationality restrict areal expansion and optimisation of AfDE cultivation, curtailing growth and structuring a social-ecological system in dynamic equilibrium. Our findings underline that sustainability is not simply a physio-technical issue; social and belief issues appear to be far more important in framing behaviour in traditional agro-ecosystems.
\end{abstract}

( 2015 The Authors. Published by Elsevier Ltd. This is an open access article under the CC BY-NC-ND license (http://creativecommons.org/licenses/by-nc-nd/4.0/).

\section{Introduction}

Growing recognition of the need for more sustainable alternatives to industrial farming, such as agroecology (De Schutter, 2011), conservation agriculture (Hobbs et al., 2008), organic farming (Foley et al., 2011:339) and ecological intensification (Tittonell, 2014) has led to a revival of interest in the potential of traditional agro-ecosystems. Traditional agro-ecosystems have inspired many of these alternatives because they generally exploit locally available and renewable resources, emphasising nutrient recycling and biological maintenance - rather than inputs of

\footnotetext{
* Corresponding author. Tel.: +44 01524592196.

E-mail addresses: james.angus.fraser@gmail.com (J.A. Fraser), victoriafrausin@gmail.com (V. Frausin), a.jarvis@lancaster.ac.uk (A. Jarvis).
}

exogenous and finite resources such as agro-chemicals (Altieri, 2002; Gliessman, 2007; Perfecto et al., 2009). Traditional agroecosystems are fundamentally social and physical-technical systems (Berkes, 2008; Cleveland, 2014), yet owing to disciplinary specialisations, few studies have examined the interactions between both these dimensions in a single system. A central question in this debate pertains to the relationship of these dimensions of food production to the sustainability of traditional agro-ecosystems over time. For a system to be considered sustainable it needs to be shown to have retained key characteristics for several generations (WCED, 1987). In order for us to explore this question we need to look at the social institutions through which the practices of ancestral generations are reproduced by the current generation, and how this contributes to sustainability of the system. For this reason, case studies demand a location where intergenerational transmission of agro-ecological 
knowledge and practice is ongoing. It is especially important to understand this from the perspective of alternatives to industrial agriculture such as agro-ecology whose stated goal is sustainability (not just productivity per se which is the case for conventional agriculture) (Vandermeer, 2011).

This paper examines the intergenerational transmission of social and physical-technical dimensions of a traditional agroecosystem of the Loma people in NW Liberia. We engage an innovative interdisciplinary methodology that brings together analyses of energetic efficiencies in food production and intergenerational transmission of social and agro-ecological knowledge. Our case study focuses on African Dark Earths (AfDE) - fertile carbon-rich anthropogenic soils forming through the highintensity deposition of fresh and charred wastes over time - in the Upper Guinea forest, West Africa. Commentators assert that anthropogenic dark earths potentially provide a model for increased crop production on inherently infertile tropical soils whilst reducing environmental impacts and sequestering carbon (Glaser, 2007; Glaser et al., 2001; Kawa, 2008; Schmidt, 2013; Sombroek et al., 2002, 2003; Steiner et al., 2003). Examination of the relationship between social and physical-technical dimensions of dark earth systems requires a locality where the formation of these soils is on-going as a continuous, site-specific practice over generations.

Anthropogenic dark earths are most well known in Amazonia as terra preta (Glaser and Birk, 2012; Schmidt et al., 2014), yet it is difficult to examine this relationship in Amazonia since the societies that produced these soils, and the social institutions and agro-ecosystems associated with them, are virtually extinct (although see Schmidt, 2013). The recent discovery that extant indigenous societies of several West African countries - in particular the Loma of NW Liberia - are still producing and utilising anthropogenic dark earths provides the opportunity to explore this relationship. AfDE have double to triple the amount of organic carbon, significantly higher $\mathrm{pH}$, cation exchange capacity and more plant-available nutrients when compared to background oxisols (Solomon et al., n.d.). AfDE are produced through the deposition of charred and fresh everyday refuse at the same locales where domestic or food production activity take place over multiple generations (Frausin et al., 2014). These characteristics are important to farming in areas such as West Africa that are characterised very old highly weathered oxisols that are of limited agricultural potential owing to generally low $\mathrm{pH}$, limited contents of plant available nutrients and high iron and aluminium content (Mouinou et al., 2013). AfDE extent and patterning in the landscape tracks the movement, intensity and duration of everyday domestic activity at settlements over time - which is shaped by a multiplicity of factors including kinship, marriage and warfare. Rather than being intentional as such, the formation and specific patterning of AfDE is the inevitable outcome of shifting sociocultural, political, and historical factors interplaying with the practical and inevitable effects of everyday life (Fraser et al., 2014). AfDE form through largely unreflective domestic, food and plant processing practices through time and space - a habitus - the everyday taken-for-granted routines and activities that structure the possibilities for action (Bourdieu, 1977). The relationship of social institutions to the physical-technical functioning of AfDE traditional agro-ecosystems is poorly understood, however.

In the study of West African societies it is well established that social institutions are central to a multiplicity of factors in food production systems, including labour availability, land tenure, and natural resource management decision making (Fairhead and Leach, 1996, 2005; Leach, 1994; Richards, 1985, 1986, 1993). Not only are social institutions inseparable from food production practice, but for many traditional peoples in Africa and elsewhere, social institutions are also inalienable from the ritual and religious
(Appiah-Opoku and Hyma, 1999; Awuah-Nyamekye and SarfoMensah, 2011; Berry, 1989; Bloch, 2008; Byers et al., 2001; McCaskey, 1995; Mowo et al., 2013; Parrinder, 1961; Sasaoka and Laumonier, 2012; Ubink and Quan, 2008; von Heland and Folke, 2013; Wadley and Colfer, 2004). Many Sub-Saharan African societies - including the Loma - have traditionally believed that their ancestors have mystical powers and a functional role in the world of living kinsmen. There is an indissoluble unity between the living and the dead and between what in the West we call the 'religious' and the 'social' (Bloch, 2008). In many African languages the same word is used for living elders and for dead ancestors who have much the same powers of blessing and cursing (Kopytoff, 1971). The relationship of people to their ancestors forms a "remarkably uniform structural framework" (Calhoun, 1980; Fortes, 1965) across Sub-Saharan Africa and is crucial in access to land. The past is said to have a "powerful presence" in many aspects of Upper Guinea societies to which the Loma belong (Knörr and Filho, 2010) because it is through ancestor worship and the power associated with them that their (real or fictive) descendants can access land. The importance of ancestors in people's everyday lives in the suggests they live on supra-biographical timescales (rather than that of an individual lifetime) (MacCormack, 1986; Paulme, 1954), and this has implications for questions of sustainability.

In this paper we develop a notion of 'ancestral habitus' to conceptualise the ways in which people's belief in ancestors, interactions with them through ritual practice, and the desire to inhabit the same spaces as them shapes a patterned tendency for people to co-locate with ancestors in the landscape, and reproduce the same patterns of activity in the same places across generations. Belief in ancestors also structures decision making (in particular, who can farm where, which areas of forest must be conserved) in Sub-Saharan African societies. Sub-Saharan African ontologies wherein ancestor worship and associated habitus are central contrast with the more recognisably self-interested economic rationality seen to typically motivate individual and group actors in the West. We express this distinction theoretically, drawing on Polanyi's notions of formal and substantive economy (Polanyi, 1957). In this framing substantive rationalities tend to be more characteristic of non-industrial societies structured by institutions of reciprocity and redistribution upholding social order, with economic activity shaped by and diverse kinship, religious and political institutions. In contrast, formal rationalities emerge in industrial and late-industrial societies with delocalized economies dominated by 'the market' wherein people often act as selfmaximising individuals in the neoclassical sense. These two rationalities are by no means mutually exclusive and may both operate in the same societies and even in the same individuals. The work of anthropologists and others looking at traditional economies in non-industrial contexts has provided significant support for (as well as some critique of) the empirical reality of the notion of the substantive economy (Bohannan, 1955; Gudeman, 2001; Hann and Hart, 2011; Sahlins, 1972). In addition, a growing body of work in psychology suggests that the sacred values (i.e. in ancestor worship) that structure substantive rationalities are processed based on rights and wrongs irrespective of outcomes, in stark contrast to the typical utilitarian costs and benefits analysis characteristic of formal rationalities (Atran et al., 2007; Berns et al., 2012; Ginges et al., 2007). In the post-Colonial period a variety of factors including modernity, urbanisation, warfare, Christianity and Islam and western-led development models have, however, led to partial or complete transformations from substantive to formal rationalities amongst Sub-Saharan African peoples, in particular children and youth, although this is not to deny that these two forms of rationality, which could also be expressed as the 'customary' versus the 'modern' can coexist or hybridise (Honwana 
and de Boeck, 2005; Janson, 2013; Newell, 2012). In our case study, a youth emboldened through participation in the recent war (1990-2005) has begun to challenge customary authority along with ancestor worship and associated habitus in natural resource management and land use and tenure.

The paper is arranged as follows: Section 2 outlines the characteristics of our case study area and the three major kinds of food production system operating within it. It describes the methods used to gather quantitative longitudinal panel survey data and calculate calories produced per unit of labour; along with qualitative methods used to gather data on social institutions and practices. Section 3 presents and discusses quantitative findings on Loma food production efficiencies before moving on to contextualise them drawing on qualitative data in three sub-sections on how ancestral habitus shapes management of AfDE at farm kitchens, towns and old town spots, respectively. The final subsection looks at the costs and benefits of ancestral habitus to the Loma in order to try and differentiate between substantive and formal rationalities in shaping use of AfDE for food production. Finally, Section 4 reflects on the implications of our findings for understanding the central role of intergenerational social institutions in the sustainability of social-ecological systems.

\section{Study area and methods}

This research draws on 9 months of fieldwork in NW Liberia conducted between August 2010 and July 2011, for which prior permission was obtained from all informants interviewed, regional leaders, and officials of the Government of Liberia.

An initial survey in Bong, Lofa and Nimba counties in northwestern Liberia found AfDEs at over 134 locations (Fraser et al., n.d.). AfDE are associated with Mande macro-language speaking groups such as the Loma who are thought to have arrived in the area some 500 years ago following the breakup of the Mali Empire and the desiccation of the Sahel (Brooks, 1989). AfDE in this region can be divided into three types: The first form underneath and around farm kitchens and palm oil production pits. The second consists of rings of dark soil currently forming around towns, villages and hamlets. The first two AfDE types are used as kitchenand home-gardens and are still in formation because they are semi-continuously receiving charred and fresh organic material. The third constitute relic AfDE at the site of former settlements ('old town spots' in Liberian English). These sites are covered with mature rainforest species associated with human settlement such as Bosqueia angolensis, Margaritaria discoidea, Pycanthus angolensis, Ricinodendron heudelotii, Sterculia tragacantha, Blighia sapida, and Ceiba pentandra and tree-crops Kola (Cola nitida) and Cocoa (Theobroma cacao) (Fraser et al., n.d.). Customary law prohibits the clearing of biomass in order not to disturb the ancestors, graves and individual trees linked to living and dead people that characterise these spaces (see Sub-sections 3.4 and 3.5. These sites are used for ritual initiation society activities. Hence, we refer to these as "sacred agroforests" because they combine the characteristics of sacred forests (Sheridan and Nyamweru, 2008) and agroforests. Sacred agroforests are established around current settlements and then expand to cover old town spots upon abandonment (see Sub-sections 3.4 and 3.5)

All agriculture is rain-fed and the region has an average annual rainfall of $2900 \mathrm{~mm}$ capable of supporting wet evergreen forest (Poorter et al., 2004:10). The majority of rainfall occurs between July and November. The geomorphology of the landscape is characterised by low rolling hills that form a hill to valley continuum within which three major physio-hydrographic positions are distinguished by their soil and the source of water for cultivation. These are pluvial (hilltop, cultivation reliant on precipitation), phreatic (hillside, groundwater from high water table) and fluxial (valley bottom water from surface flow, i.e. runon and flooding by streams). Natural soils at the top of the toposequence are typically infertile and highly leached oxisols or ultisols, whilst those towards the bottom are more fertile inceptisols and entisols (Andriesse and Fresco, 1991).

\subsection{The Loma settlement Wenwuta and its territory}

Following the initial survey, Wenwuta, a Loma settlement in the Southern Zorzor district of Lofa county, NW Liberia (Fig. 1), was selected for an in depth case study since this relatively remote area is characterised by a high degree of cultural continuity where traditional agro-ecosystems have persisted for generations. The population derive the majority of their food from their ca 1000 ha territory with no chemical fertilizers or pesticides and extremely low fossil fuel use. Speakers of languages such as Loma who belong the Mande macro-language family of the Upper Guinea Forest display an astonishing cultural resilience in the face of centuries of warfare, socio-political change and (across the border in Guinea) state repression of their native religion (Hojberg, 2007; McGovern, 2012). Societal resilience in the face of constant ecological and social disturbance is attested to through oral histories and written accounts (Fairhead et al., 2003) which show that $100-150$ years ago settlements were similarly sized yet faced many similar challenges with diseases, warfare and resource management. The Loma are a farming society that lives in dense hierarchical settlements, and important social institutions include various male and female initiation societies, and associated ritual and religious practice, including ancestor worship (Hojberg, 2007; Leopold, 1991). Initiation societies are gender specific, semi-secret cults that perform ritual divinations and sacrifice to protect individuals and groups, and to initiate male and female individuals (Bledsoe, 1984; d'Azevedo, 1962, 1989; Ellis, 2007; Fahey, 1971; Fulton, 1972; Little, 1965, 1966; Murphy and Bledsoe, 1987; Zetterström, 1980).

Wenwuta is a settlement of $\sim 250$ people and around 2.5 ha in size. Radiocarbon ${ }^{14} \mathrm{C}$ analysis from visible intact char particles collected from the lowest horizon of a deep AfDE soil profile of $(1.8 \mathrm{~m})$ at Wenwuta was performed by the Accelerator Mass Spectrometry (AMS) facility at the AMS ${ }^{14} \mathrm{C}$ Dating Centre, Department of Physics and Astronomy, Aarhus University, Denmark (Solomon et al., n.d.). This yielded a calibrated dating of 1670-1682. Written accounts confirm that Wenwuta existed in the mid- nineteenth century because it was described by African American explorers who visited the region (Fairhead et al., 2003:132). Hence, we estimate that Wenwuta was founded towards the end of the seventeenth century, and has been continuously occupied since.

Wenwuta is relatively isolated from the rest of Liberia, a $7 \mathrm{~h}$ drive from the capital Monrovia, the final four on non-paved roads. At the time of research it had no road and access entailed a $40 \mathrm{~min}$ walk from the closest car-worthy road. Most food consumed is grown (crops), gathered (oil palm) or caught (fish, bushmeat) by the community, with a proportion traded in the Saturday market in a neighbouring town, Zolowo.

The Wenwuta territory consists of an area of around 1000 ha (Fig. 2). The territory is defined by townspeople as the total area exclusively available for Wenwuta people to practice all three food production systems. Apart from the town of Wenwuta itself and its rice fields, farm kitchens and areas of sacred agroforest, the territory is covered with secondary forest vegetation at various stages of regrowth characterised by Albizia altissima, Octoknema borealis, Pentaclethra macrophylla, Funtumia elastic, Uapaca esculenta, Parinari excelsa, Cryptosepalum tetraphyllum and Elaeis guineensis (Fraser et al., n.d.). Neighbouring satellite villages and hamlets are not included in this territory - their food production 


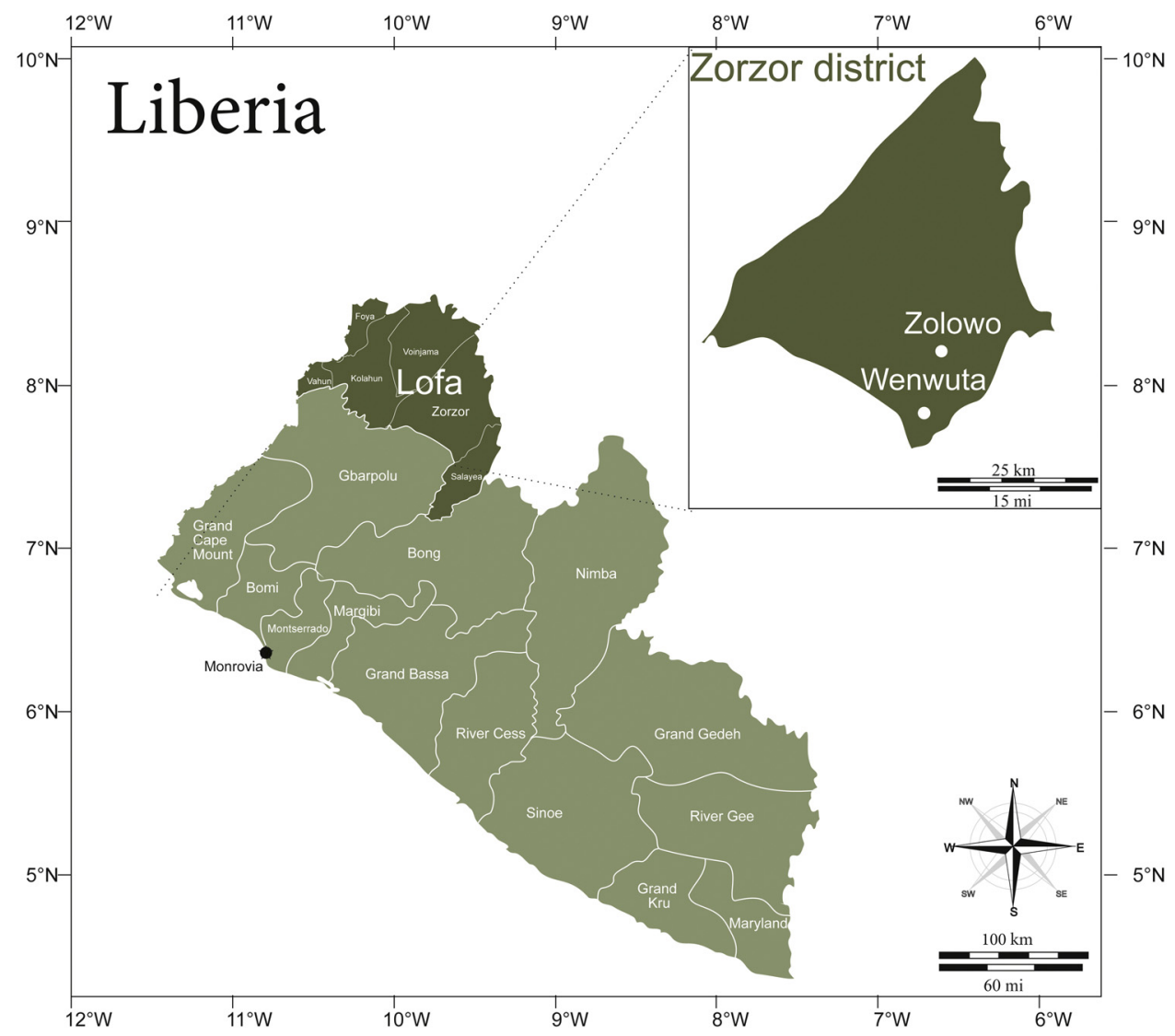

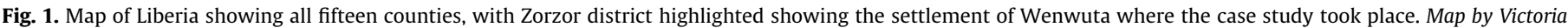
Frausin.

systems are located outside the Wenwuta territory. We assume that this territory has been associated with Wenwuta since the founding of the town in the late seventeenth century.

\subsection{The three food production systems operative in Wenwuta territory}

Within the territory, and indeed all the regions surveyed in NW Liberia, 3 basic kinds of food production system are operative: (1) Extractivism (taking place throughout the 1000 ha Wenwuta territory (Fig. 2, the area within the purple line) mostly comprised of a secondary forest mosaic bisected by small rivers and streams); (2) Upland shifting cultivation of rice (50 ha of new fields $\mathrm{y}^{-1}$ ); (3) AfDE kitchen and home gardens ( $3 \mathrm{ha}$ ). We now describe each in turn:

In this paper, we use 'extractivism' to signify the exploitation of 'wild' food and fuel sources, a traditional livelihood activity practiced by tropical forest dwelling peoples around the world (Arnold and Perez, 2001; Kusters et al., 2006). Extractivism can be distinguished from agriculture in that the plants and animals it exploits are typically wild and non-domesticated, although in this region of West Africa, as in many other tropical forest contexts around the world, hunting and gathering occurs in both 'disturbed' or 'anthropogenic' forest environments, along with more 'pristine' ones (Marshall and Hawthorne, 2012). Similarly, although species gathered are typically self-propagating, human agency often shapes distribution, intentionally or not. For example, disturbance by shifting cultivation encourages oil palm expansion. In NW Liberia, the most common extractivist activities carried out are the collection and processing of oil palm (E. guineensis) fruit heads, fishing, hunting and the collection of fuelwood and medicine.
Shifting cultivation is one of the oldest forms of agriculture in existence and remains one of the most common forms of agriculture practiced by smallholder farmers across the tropics (van Vliet et al., 2012), although systems are highly diverse and locally specific (Brookfield and Padoch, 1994). In West Africa, rice (Oryza spp.) is the carbohydrate staple, and a distinction is typically made between shifting rice cropping systems in the uplands and permanent, wet rice cropping systems in the lowlands (Richards, 1985). In our study region the majority of rice is produced in an upland shifting cultivation system, but in practice rice fields often cut across different toposequence positions (Leach, 1994; Richards, $1985,1986)$. Around 50 ha of new rice fields are cleared yearly in Wenwuta territory during beginning of the dry season (Nov-Jan) with axes from fallow vegetation aged from 7 to 15 years, left to dry for a few months before burning (Mar-May), and then rice is planted (May-July). After harvest (Oct-Dec), in the second and even third years, areas within the fields are cleared, reburnt and planted with groundnut (Arachis hypogaea), beans (Vigna spp.) and manioc (Manihot esculenta) (Leach, 1994).

AfDE kitchen and home gardens are located at sites where long term domestic and/or food processing activity is on-going, either in the bush at locales used as farm kitchens or palm oil production pits, or around the edges of towns at kitchen sites. AfDE homegardens are most commonly cultivated with plantain (Musa spp.), cassava (M. esculenta) and taro (Colocasia esculenta). These species are cultivated year-round and the homegardens continue to receive soil amendments from everyday food processing and domestic activity. Because food production is year round, AfDE kitchen gardens provide a significant amount of calories and broaden household choice of foodstuffs. They also provide a degree 


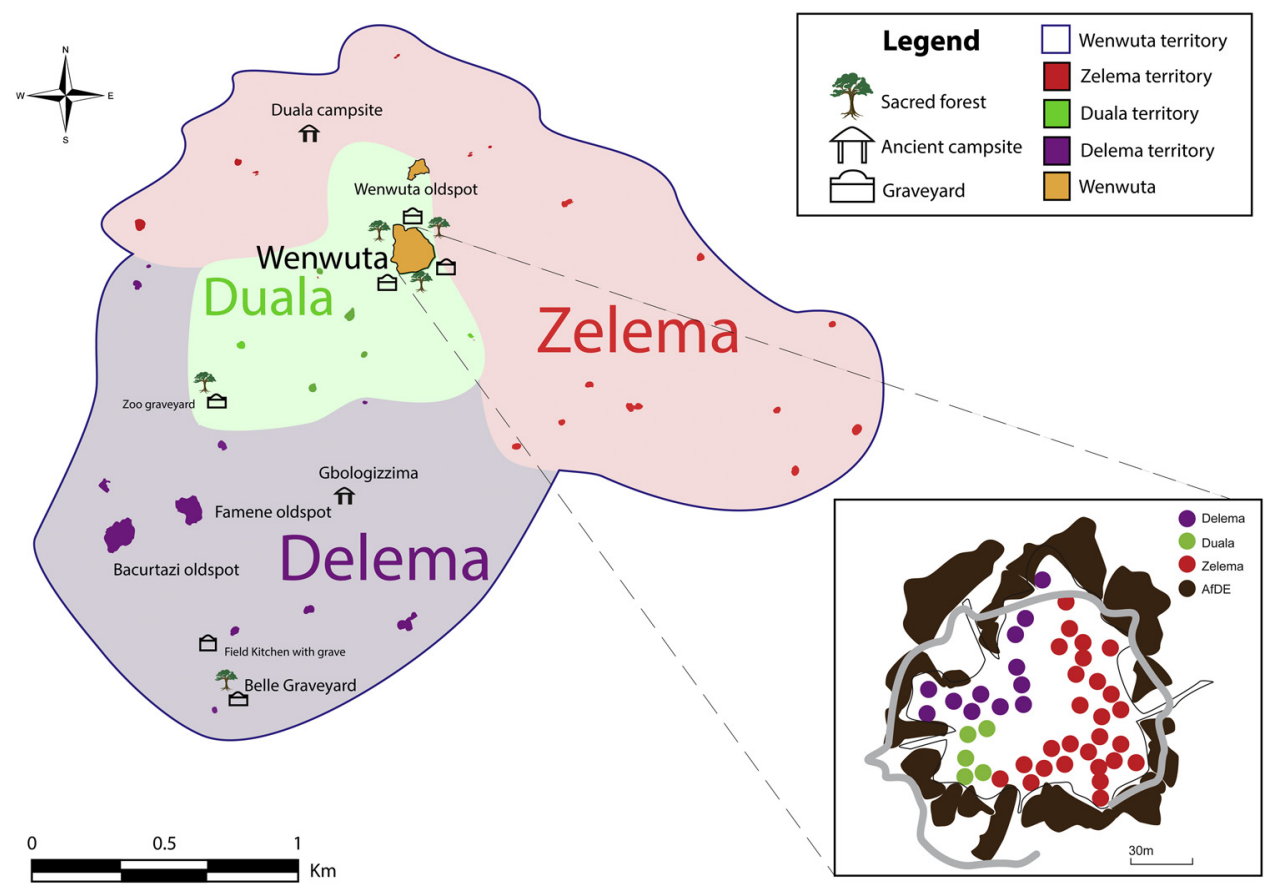

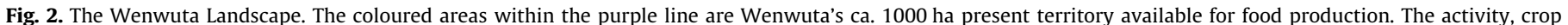

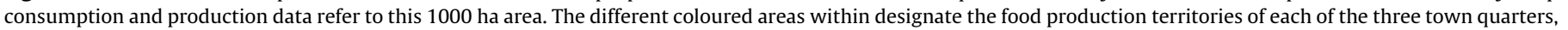

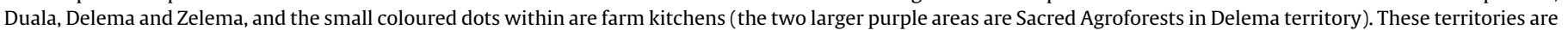

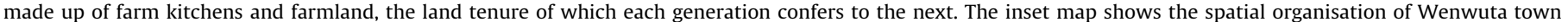

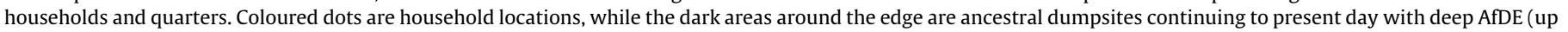

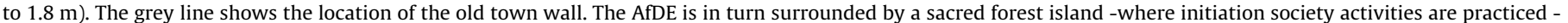

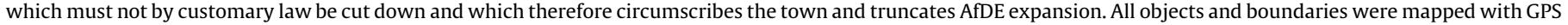

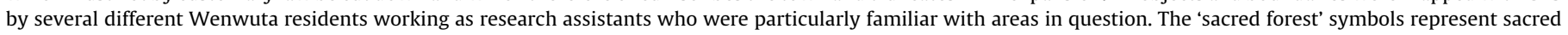

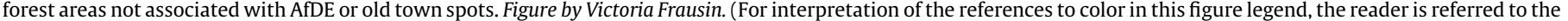
web version of the article.)

of food security in times of rice scarcity (Aug-Oct, before the rice harvest) (Fraser et al., 2014; Frausin et al., 2014).

\subsection{Methods}

To generate data for calculating food calorie production versus calorie expenditure in labour of the three food production systems we developed two longitudinal panel surveys. Survey One was designed to capture patterns of everyday food consumption and the number of days spent labouring in each food system. Survey Two was designed to measure the relative quantity of food that was sold in local markets from each production system. The two surveys were both intended to run for 18 months. They were initially conducted by JAF and VF, with a local research assistant trained to continue on their departure. However, Survey One was only conducted for six months, from March to September 2011, while Survey Two was conducted for the full 18, between February 2011 and May 2012. This was because the research assistant felt they only had time to be able to continue with Survey Two.

Survey One measured household food consumption and household labour allocation patterns. We randomly selected 15 households from a subsample of 34 households willing to participate in the study (from a total of 45) and on two random days per week we visited them after the evening meal. We asked people: (1) Which kinds of foods they had consumed that day and which of the three land use systems provided each of them. Meals composed of various foodstuffs were typically broken down into constituent parts e.g. rice, leaves, palm oil and meat, each of which when mentioned counted as one 'food item.' (2) Which of the three food production systems they had been working in that day. This was to enable us to measure the relative number of days spent labouring in each system. Each day spent working in a food system counted as ' 1 '. We assumed that a day's labour in an AfDE kitchen or home garden, a day's labour in shifting cultivation, and a day's labour in extractivism are equivalent.

Survey Two recorded produce sold by Wenwuta people once a week at the Saturday market in Zolowo, a nearby town (Fig. 1). This survey captured calories being exported out of the system. Before the market we visited every household in our sub-sample of 34 and recorded the quantity of each product that they were sending to market and the system within which they were produced. On their return from market we recorded the prices that they had received for each product. In this way we measured the quantity and value of products coming from each production system.

\subsection{Calculating calorie/labour efficiencies}

We consider efficiency to be food energy produced per unit labour, $e$, defined here as the ratio of food calories produced within the system, $E$, to hours worked to produce this food, $W$.

$e=\frac{E}{W}$

Although strictly speaking this is not an input-output efficiency, the definition of $e$ suffices for this study because we are only interested in the comparative efficiencies between the three food production systems.

We calculated total calorie production, $E$, as follows. For food consumed locally, $E_{C}$, based on field observations we calculated how much by weight of each food item was typically consumed per meal per person. We did this by weighing 18 different plates of food (dividing them into portions of each food item that composed 
the plate of food) being consumed by three male and three female children aged 5-15, three male and three female young adults aged 15-30, and three male and three female elder adults over the age of 30 at eight randomly selected households on eight different occasions every two to three weeks between February and July 2011. We assumed that this pattern of consumption continues year round. We used the United States Department of Agriculture (USDA) food calorie database to assign a calorie count to each food item based on the average amount consumed per meal, assuming that the Wenwuta food types mapped directly to these USDA figures Calorific values of bushmeat (mammals and rodents) consumed and sold were taken from Malaisse and Parent (1982).

We then summed these average calories per typical weight consumed by the average individual for each mention of each food item coming from each food production system (Table 1). We scaled up this average individual consumption to the system level by multiplying by the average number of household occupants (5.7) and the number of households in the study area (45). For net food imports/exports traded through the local market, $E_{T}$, we again assigned calorie per gram values for each category of food item and then summed calories for each category by weight traded from each different production system. The total calories produced is then simply the sum of the total calorific energy consumed and traded, $E_{C}+E_{T}$ and this is estimated for each food production system (extractivism, shifting cultivation, AfDE). For reference we also scale the calorie yield of each of these systems by food system area. In order to calculate the food energy produced per unit labour - which we use as an efficiency index, $e$, for each of the 3 production systems - we simply divide the total calorific energy produced in each system $(E)$ by the sum of recorded days spent labouring $(W)$ in each system.

To investigate social institutions we used qualitative methods including participant observation, open interviews $(n=43)$ and oral histories ( $n=37$ ) with Wenwuta residents during the course of daily activities such as sharing meals, rice farming, palm oil production, domestic household activities, and drinking Raffia vinifera wine in the evenings. We selected interviewees based on their willingness to be interviewed and sought to balance age and gender. We interviewed equal numbers of men and women in different age categories: youth ( $<30$ years old), mature adults (ca. 30-50 years) and elders (ca. 50+). All were subsistence farmers. Interviews were conducted in Liberian English and Loma, with our assistant, Woulay Narmah, translating the Loma. We mapped the Wenwuta territory and its three food production systems in an exercise combining participatory GPS mapping and transect walks with key informants who walked with us in order to track and map the limits of their entire territory, fields and AfDE patches (towns, old town spots, villages and farm camps) (Fig. 2).

\section{Results and discussion}

The results and discussion section is organised into subsections. Sub-section 3.1 presents and discusses the implications of efficiency and GPS mapping findings in relation to Loma food production, oral histories and soil profile data, which throw up a set of questions which are then addressed in the remainder of the paper. Sub-section 3.2 discusses the importance of ancestral habitus, and the ways in which this key principle shapes natural resource management is examined in sub-sections 3.3 to 3.5 in relation to AfDE at farm kitchens, towns and sacred agroforests on old town spots, respectively. Finally, sub-section 3.6 looks at the demands that ancestors place on the living, and the benefits that continuing co-location and ritual confer onto the living.

\subsection{The efficiency of Loma food production systems}

The food energy produced per unit labour - our index of efficiency, $e$, for each of three food production systems operating in the 1000 ha territory of Wenwuta was : 7 (MJ/day) for extractivism, 7 (MJ/day) for shifting cultivation and 16 (MJ/day) for AfDE (Table 1). Hence, AfDE systems were, on average, more than twice as efficient as either shifting cultivation or extractivism in producing food calories. There are uncertainties with these quantitative data, most significantly that our longitudinal surveys of food consumption and labour data only spanned six months as compared with eighteen months of food sale longitudinal data. Moreover, our data do not capture whether work is harder in different systems. Whilst this means our averaging out misses important daily and seasonal variation in both calorie production and labour demands - our findings, when backed up with evidence from open interviews are robust enough to conclude that AfDE food production around settlements and farm kitchens is significantly more efficient at producing calories for labour expended than the two other food production systems operative in Loma territory. The reasons for such large differences in the observed productivity of these different land use types are twofold. Firstly, as described previously, AfDE are intrinsically more fertile than the background soils within which they form. A possible additional factor is that shifting cultivation and especially extractivism entail significantly more dispersed activity and hence more labour is probably expended on getting to, working and harvesting from these systems when compared to the highly localised AfDE systems.

Despite the greater efficiency of AfDE food production, participatory mapping revealed that total AfDE coverage (i.e. the aggregate of all AfDE occurring around (i) farm kitchens and palm oil pits; (ii) Wenwuta town and (iii) old town spots) amounts to only ca. $0.5 \%$ or ca. 5 ha of Wenwuta territory. AfDE around farm kitchens and palm oil production pits (each on average $100-500 \mathrm{~m}^{2}$ in size) collectively constitute about 2 ha or $0.2 \%$ of the Wenwuta territory. Wenwuta itself is surrounded by a cultivable area of AfDE up to $1.8 \mathrm{~m}$ deep and 1 ha in size, or $0.1 \%$ of the Wenwuta territory. Relic anthrosols at the site of former settlements (old town spots) and in Wenwuta territory cover an area of 2 ha or $0.2 \%$ of Wenwuta territory (Fig. 2). Because these old town spots are used as sacred agroforests, produce non-food tree

Table 1

Calculation of efficiencies in three food production systems operating in the territory of Wenwuta, a Loma settlement in north-western Liberia.

\begin{tabular}{|c|c|c|c|}
\hline \multirow[b]{2}{*}{ Parameter } & \multicolumn{3}{|c|}{ Food production system } \\
\hline & Extractivism & Shifting cultivation & AfDE \\
\hline Food energy consumed (MJ/year) & 165713 & 418225 & 117019 \\
\hline Food energy traded (MJ/year) & 8406 & 4949 & 6736 \\
\hline Food energy produced (MJ/year) & 174119 & 423174 & 123755 \\
\hline Labour input (days/year) & 24570 & 62790 & 7644 \\
\hline Land area (ha) & 1000 & 50 & 3 \\
\hline Labour input per unit land area (days/ha/year) & 25 & 1256 & 2548 \\
\hline Food energy produced per unit land area (MJ/ha/year) & 174 & 8463 & 41252 \\
\hline Food energy produced per unit labour (MJ/day) & 7 & 7 & 16 \\
\hline
\end{tabular}


crops and are controlled by men residing outside Wenwuta territory, their produce was not captured by our surveys and hence excluded from our analysis. Hence, of the 5 ha of AfDE in Wenwuta territory, only 3 ha were used for food production by Wenwuta people themselves. Given that oral histories indicate that AfDE have withstood intensified cultivation for centuries (Fraser et al., 2014), we can conclude that AfDE has maintained this productive advantage in the long-term.

Oral histories and soil profile data also appear to suggest that AfDE forms relatively rapidly. A village close to Wenwuta, New Gbokolomie, was founded within the living memory of its current chief, an elder of around eighty years old (this assertion was verified with other elders of the village and from Wenwuta). A soil pit dug there revealed AfDEs to a depth of ca. $90 \mathrm{~cm}$ (Fig. 3), suggesting its formation at $\mathrm{ca} .1 \mathrm{~cm}$ a year, assuming dumping is carried on regularly (without moving to a different dump area). Hence, this village, which currently has around .25 ha of AfDE could theoretically have up to 1 ha of AfDE had dumping been strategically expanded rather than concentrated in the same areas.

Given the speed at which AfDE form therefore, we infer that they could readily be expanded without much additional labour cost given their location at sites of domestic activity where biomass is brought from the surrounding hinterland, yet the Loma have not expanded them. The Loma are fully aware that their activities produce AfDE, they recognise that it is the 'dirt' that they and their ancestors discard makes soil more fertile (Frausin et al., 2014). Formal rationality would predict expansion of AfDE until the distribution costs of the kitchen residues meant that the calorie/labour efficiencies of AfDE approached those of extractivism and shifting agriculture. In the following sub-sections we draw on qualitative material in order to explain why Wenwuta people forego on the obvious opportunities to increase production that are presented by AfDE efficiencies. We argue that the Loma forgo on possibilities to expand AfDE coverage not because they are determined by their environment, ignorant or incapable of innovating, but rather because there are cultural bounds which restrict the expansion or optimisation of each of three kinds of AfDE (farm kitchens, settlements, old town spots). We argue that these bounds contribute to the long term sustainability of the Loma social-ecological system.

\subsection{Ancestral habitus and its contestation in Loma natural resource management}

The following four sub-sections describe the ways in which the centrality of ancestor worship and its associated habitus in Loma ontology shapes what we characterise as a Polanyian substantive economic rationality in natural resource management and food production practices. We also describe how youth involvement in the 1990-2005 war has led to the emergence of a competing Polanyian formal economic rationality amongst the Loma which is leading to situations wherein the latter challenges the former.

Loma informants recognised in interviews that AfDE are the most highly productive soils, the best places for permanent gardens (Fraser et al., 2014; Frausin et al., 2014). They associate them with the ancestral nature of domestic spaces, common assertions including: 'we woke up, we saw them' [around our living spaces], and 'they were made when our way back people threw dirt there,' signalling that the soils have been present in the same place since the informant became conscious and that their genesis lies in ancestors' dumping activities. However, this tendency to conceptualise AfDE as part of domestic (and therefore best suited for homegardens, rather than for shifting cultivation) rather than agricultural spaces per se explains how ancestral habitus functions to limit expansion. If a space is conceived of as a living space, (whether or not it also features crop cultivation) any possible expansion is conceived of in terms of expanding that ancestral living space, not agricultural expansion (and hence increased production) as such. a

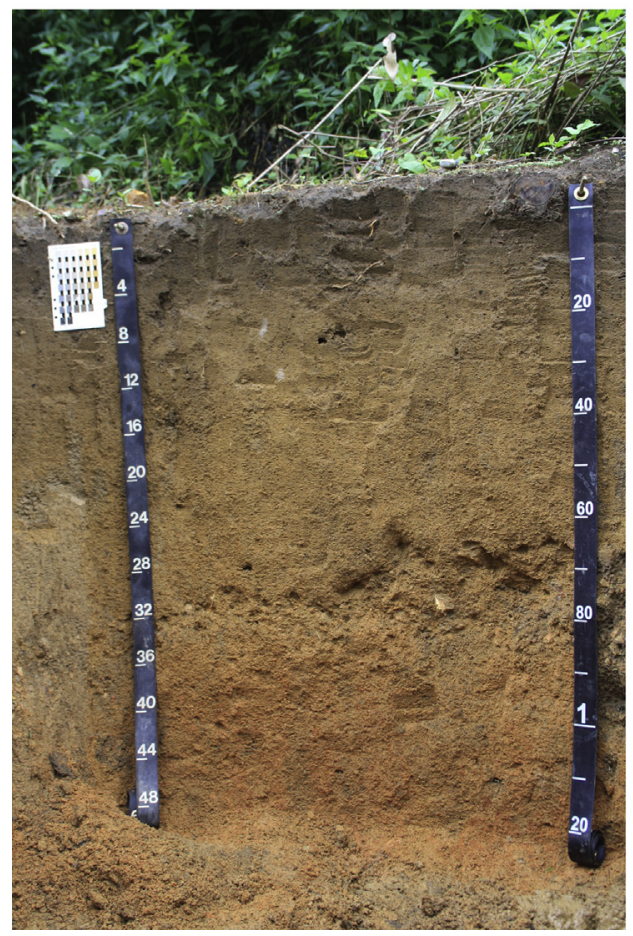

b

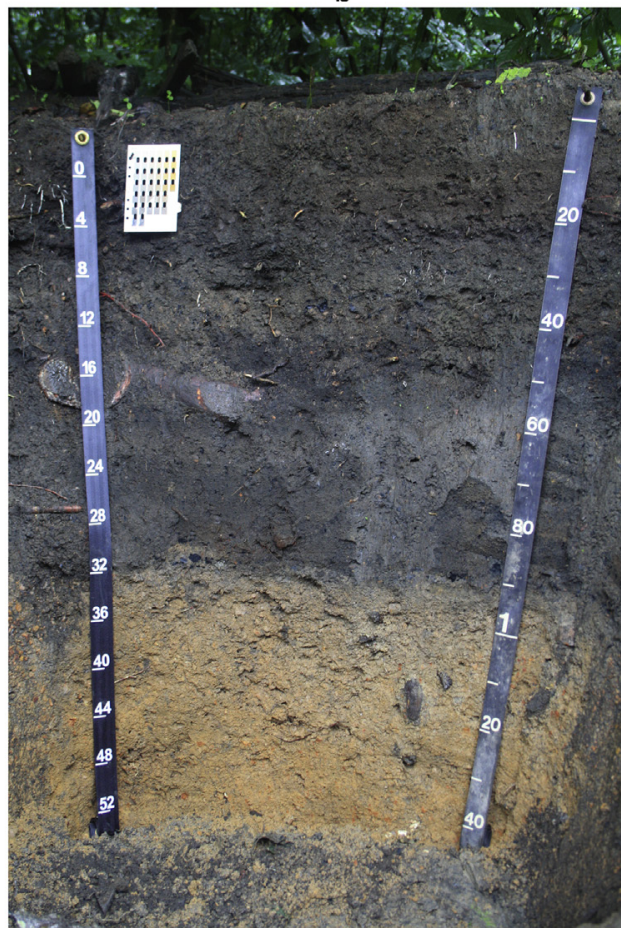

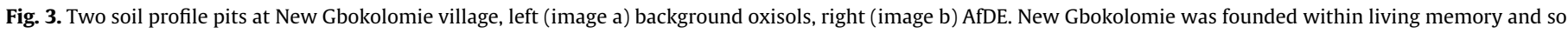
assuming the age of elders who recall the village to be eighty, AfDE forms at the rate of around $1 \mathrm{~cm}$ a year. Photos by Victoria Frausin. 
Our participatory mapping revealed that land available to members of each of Wenwuta's three town quarters today forms an historic territory where ancestors used to locate their farm kitchens, practice farming and extractivism (Fig. 2). The present day farm kitchen sites of each family and fallows available for shifting cultivation are coterminous with their ancestors' kitchen sites and historic farming areas. These territories contain graves and sacred groves and spaces associated with ancestors that both symbolically manifest their presence (and so the tenurial rights of the living who claim descent) but also serve to protect certain areas of the landscape from clearing and biomass burning for farming (Fig. 2). Given that land tenure ultimately rests in being able to claim kinship with firstcoming lineages and/or powerful ancestors, relationships to the dead are very important. The map of Wenwuta town inset in Fig. 2 shows that people also co-locate with their ancestors (same household spot) and their ancestors quarters (households grouped by quarter) in Wenwuta town itself.

During the recent war (1990-2005) instability caused by the arrival of different armies resulted in most of the young men joining one side or the other, and Wenwuta was attacked and burnt down several times in an attempt, according to its residents, to gain control of its relative abundance of territory compared with much larger towns surrounding it. The legitimation of land rights conferred by the centrality of ancestor worship in Loma (and by extension other Mande speaking peoples') ontology is so important to land tenure that attackers purposefully tried to kill individuals who held important secret society roles (wherein they mediated with ancestors in ritual practice) in an explicit attempt at a landgrab via cutting the ancestral link. Yet despite these disruptions, the majority of the pre-war population by the mid-late 2000s had returned to Wenwuta and surrounding towns, and land management practices continue much as before, although one difference was that some kitchens that had previously been in the town were re-located to the bush (Fraser et al., 2014). As we shall see however, the ontological centrality of ancestral worship and the habitus associated with it is now being challenged by a youth emboldened through their participation in the recent war (1990-2005). We first turn to examine how an ancestral habitus operates in each of the three AfDE systems.

\subsection{Farm Kitchens}

The domestic sphere of the farm kitchen, where everyday activities of cooking and food processing leading to AfDE production occur, is the smallest and most fundamental productive unit of Loma society (villages and towns always grow from a single kitchen spot). Single kitchens are dispersed through the bush where people reside during parts of the year requiring intensive farm work (Fig. 2) while town kitchens are adjacent to people's households in Wenwuta (inset map in Fig. 2). Kitchens in the bush and in town are loci of AfDE production - drawing in organic material from the surrounding hinterland and depositing charred and fresh residues into the soil. The key difference between the two is scale: towns feature multiple kitchens close together creating much larger areas of AfDE, whereas single farm kitchens are scattered throughout the bush with much more localised effects (Fig. 2). All Loma towns originally started as farm kitchens made by migrants or people breaking off from other local settlements.

When re-establishing farming activity after a hiatus (the most recent caused by the war that ended in 2005) people do not choose the sites to re-locate their farm kitchens to at random. They spatially co-locate the site of their kitchen with that of the known location of their ancestors' kitchen(s). These occur within the ancestral farming territory belonging to their particular town quarter, which was originally established and farmed by the ancestors of each town quarter (Fig. 2). The Loma recognise that these locations have improved soils, but rather than establish the farm kitchen beside them to take full advantage of improved soils for cultivation (which would be the 'optimal' use of resources from the standpoint of formal rationality), they invariably locate their kitchen structures in the same location as their ancestors did, and continue dumping in the same areas. These areas already feature enhanced soil fertility, and when the kitchen is reconstructed every few years it would theoretically be possible to locate the new kitchen alongside and take full advantage of improved soils whilst creating new AfDE on unimproved Oxisols for future use. Instead of doing this the Loma reproduce the habitus of living, cooking, processing food and palm, gathering wastes and dumping in the exact same spots where their ancestors performed these practices.

In the towns, the patches of improved soils do not expand because the sacred forest around the town limits expansion (see below). However, expansion of AfDE around farm kitchens is not limited by sacred forest and therefore possible. Our argument is that along with the co-location of kitchens and associated domestic, food and plant processing and dumping activities, ancestral habitus also reproduces the very fact of maintaining one's dumping activity within a circumscribed area. Since a farm kitchen is lived in the same way a town kitchen is lived, spatial continuity is reproduced through ancestral habitus even in the absence of the limiting island of sacred vegetation that surrounds towns which we now describe.

\subsection{The Town}

In towns, as with farm kitchens, people co-locate with their ancestors - contemporary house and kitchen structures are often located in the same spaces once occupied by ancestors' houses and kitchens. Moreover, people still live in the same spatial town quarter groupings that were formed when their ancestors founded the town (Fig. 2, inset map). Households have combined dump areas and homegardens which form a ring of AfDE around the town itself. Towns and villages throughout NW Liberia are typically surrounded by islands of sacred forest wherein initiation society ritual activities occur, a pattern found more broadly in both the Upper Guinean tropical forest and forest-savannah mosaic to the north which extends back generations (Duvall, 2011; Fairhead and Leach, 1996; Leach, 1994; Lebbie, 1995). To take Wenwuta as an example, there were three separate society meeting places and a 'medicine' meeting place at different locales within the forest island surrounding the town. The forest island is established during the lifetime of the town as trees are planted around it and can be considered sacred owing to this ritual activity and presence of certain trees that link to living and the dead: Ceiba pentandra are said to mark ancient grave sites of ancestors (before living memory and supposedly before gravestones were used), whilst Cola nitia are still planted today to mark the birth of a child, with its umbilical cord wrapped around the seed. The tree is then permanently linked to that individual. The head of the Wenwuta male secret society revealed to us that ancestors and some trees are seen as being endowed with a metaphysical power called sale (expressed in Liberian English as 'medicine'). An essential and enduring aspect of Loma religious and ritual practice, sale is a complex polysemic conceptual category that refers to ancestors, supernatural beings and to various embodiments of these spirits in the form of shrines, masks, divinatory media, fetish objects and herbal medicine (Hojberg, 2007; McGovern, 2012).

This 'sacred' forest island surrounds the town placing limits on expansion - because cutting it down is forbidden in customary law. This has the effect of circumscribing the area available for dumping and hence the expansion of AfDE is truncated since this would require felling the sacred forest. There is pressure to do this however. We were present at a debate where one Wenwuta youth leader advocated cutting down some of the sacred forest surrounding the 
settlement to address the problem of lack of space to build new houses. This radically disruptive suggestion, whilst ultimately rejected by elders, would have been unthinkable without the youth having been empowered through their participation in the war and the changes this experience produced in their worldview(s). This interpretation was offered by Loma youth and elders themselves in individual interviews and focus groups.

There is an important debate regarding the degree to which male youth disenchantment with a structurally inferior position (chiefs used to control youth labour and access to potential wives) was a decisive factor in their willingness to join armies during the recent wars in Sierra Leone (and by extension Liberia) (Fanthorpe and Maconachie, 2010; Peters and Richards, 2011; Richards, 1996). Our open interviews and oral histories indicate that while this was certainly a factor in actions of the youth in Wenwuta and other towns we spoke to, informants also noted that the war only accelerated an already occurring pattern of change where male youth were beginning to challenge the power of elder men. This is relevant because with youth empowerment through the war there may come a shift from a substantive rationality wherein ancestor worship and the habitus that comes with it is central, to a more recognisably formal economic rationality. Indeed, on our first visit to Wenwuta, a youth leader (mistaking our intentions) exclaimed to us: 'We want development'!

\subsection{Old Town Spots}

Towns are abandoned for a variety of reasons. The Loma claim that when trees get too big and the settlement gets "too cold," people abandon these towns and move to new spaces rather than cut down the sacred forest island. Towns may also be abandoned and relocated for historical and political reasons such as marriage, migration, and warfare (Fraser et al., 2014). Once abandoned, sacred forest expands across the town space, and future settlements cannot be re-established in the same place nor can biomass be cleared for agriculture (see next section). Loma customary laws prohibit clearance of biomass and/or fire because of the presence of ancestors and graves and trees linked to the living and dead as described above. Until a decade or so ago when efforts by government and NGOs put a stop to the practice, people who died in normal circumstances were taken and buried at these sites. Sacred forests are a phenomenon that occurs throughout Western and right across sub Saharan Africa (Chouin, 2009; Sheridan and Nyamweru, 2008).

The fact that these spaces cannot be cleared of biomass for carbohydrate staple crop production limits the use of AfDE at these sites to the aforementioned agroforestry tree-crops that are not foodstuffs. The fact that most AfDE around Wenwuta and in NW Liberia are covered with AfDE sacred (agro-) forests that cannot normally be cleared is economically sub-optimal (since it prevents farmers from diversifying and responding to changing market demand). An example of what happens when this system breaks down, or rather when formal rationality comes to be preeminent over substantive rationality in land use decisions, is instructive. In Western Nimba County (Fig. 1), the cradle of the recent war in Liberia, where youth were much emboldened through the process, we did find some instances of youth clearing old town spots covered in Sacred Agroforest in order to establish market oriented pepper (Capsicum spp.) gardens. In one instance in Nimba, we all stood in a pepper garden in the centre of an old town spot, with graves to one side, elders sheepishly explained to us that the youth had gone against their wishes and community rules. The youth seemed relaxed with their actions and sanguine in the face of the elders' admonishment. This suggests that when an ontology based on ancestor worship is ruptured, a more recognisably modern Western economic calculus may emerge.

\subsection{Furnishing the needs of the ancestors}

The preceding sections have sustained that, in carrying forth an ancestral habitus, the Loma forego on individualistic opportunities of either expanding the coverage of AfDE surrounding farm kitchens and settlements and/or cutting and burning sacred agroforest biomass on relic AfDE at old town spots to permit intensified food production. Attention to the centrality of ancestors in Loma ontology and habitus explains why they have not optimised the AfDE system in these ways, as would be expected were decision making structured by a formal economic rationality. In addition, other issues, such as access to labour, may be as significant as improved land in farming, and kinship association with ancestors is important in enabling labour mobilisation (Fairhead and Scoones, 2005). This section examines the demands ancestors place on the living, and the legitimation of territorial occupation and land tenure they confer to the living in return.

Conservation of sacred spaces confers land to the ancestors, whilst the Loma offer labour, time and energy expenditures to ancestors through various secret society rituals that performed for ancestors in Wenwuta, in initiation society areas and other special places in the landscape (Fig. 2). In return, ancestors legitimate the territorial claims of their living descendants. This explains why people continue to spatially co-locate with ancestors. Moreover, chiefly and initiation society authority is derived from genealogical claims of relation to powerful ancestors. Chiefs are vested with sacred authority since their ancestors made original pacts with the spirits of the earth and must periodically address spirits and ancestors in particular areas of the landscape (Hojberg, 2007:90; see also Leopold, 1991).

The Loma symbolically manifest their relationships to ancestors by constructing ornate graves at important and highly visible locations in the town or surrounding landscape (Fig. 3). Townspeople and visitors are constantly reminded of the relationships of those alive today with ancestors, and of the tenurial rights to areas of the surrounding landscape that ancestors confer (graves are important for similar reasons elswehere in Sub-Saharan Africa, see Fontein, 2011; Shipton, 2009). In Wenwuta, the grave of an ancestral chief, one of the present Chief's ancestors, has had an open sided house with a metal roof built over it, and is used as a meeting place where town issues are discussed, visitors received, and the town court held (Fig. 4a). Similarly, the head of the female secret society has her ancestor's grave in a central position in the town and often meets to discuss with other women whilst sitting on the grave (Fig. 4b). A man who was said to be able to 'play with leaves' (exploit latent sale powers in trees and plants) recently built a grave for a powerful ancestor just outside Wenuwta (Fig. 4c). Graves are located right through the landscape, along paths, at rice kitchens and at sacred forest groves (Figs. 2 and 4d).

Graves are of great importance, demonstrated in the amount of money and effort which is put into making them. This is enshrined in a countrywide institution: since 1916 in Liberia the second Wednesday each March is a national holiday where graves are made, often with better building materials than the houses of those who construct them (Fig. 3c). In addition to graves, the landscape of Wenwuta territory is saturated with symbols and spaces of old and current sal $\varepsilon$ that serve as spatial reminders of initiation society power and by extension to perpetuate power of first-comer lineages (Figs. 2 and 5).

\section{Concluding discussion}

The study of traditional agro-ecosystems may reveal sustainable food production practices whose key traits can be transplanted to other regions with similar environments (Altieri and Nicholls, 2013). This idea now has increasing policy traction - the 


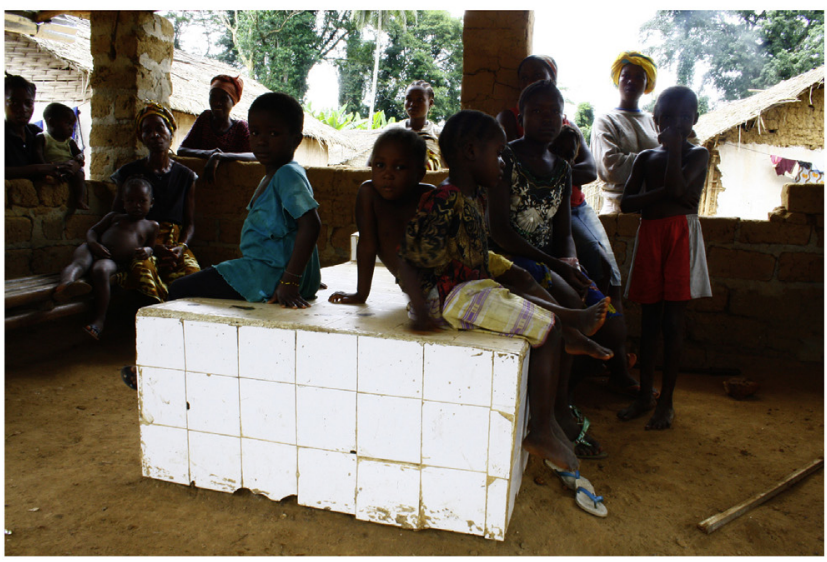

C

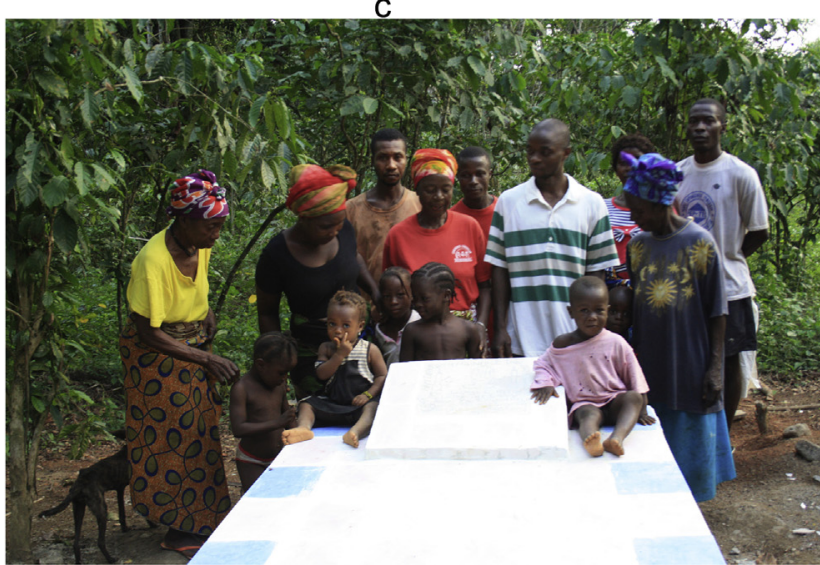

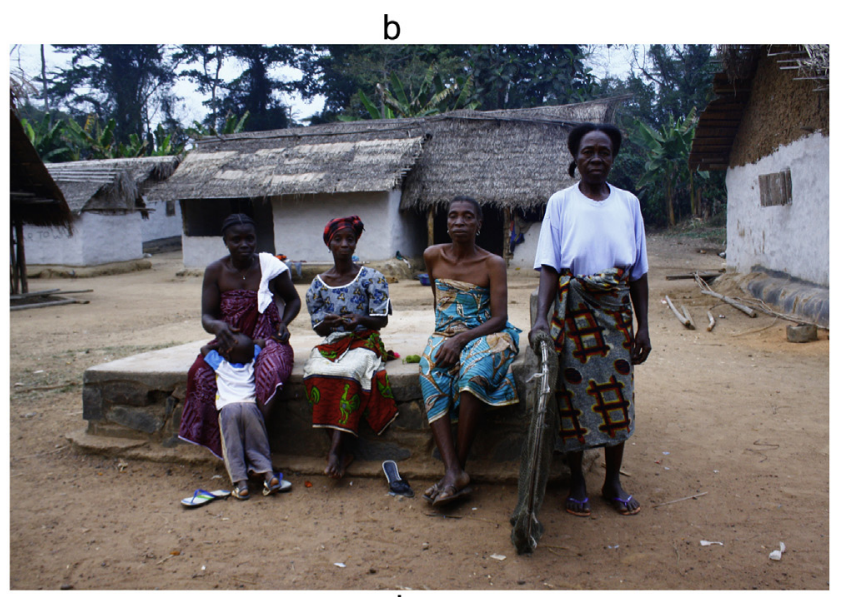

d

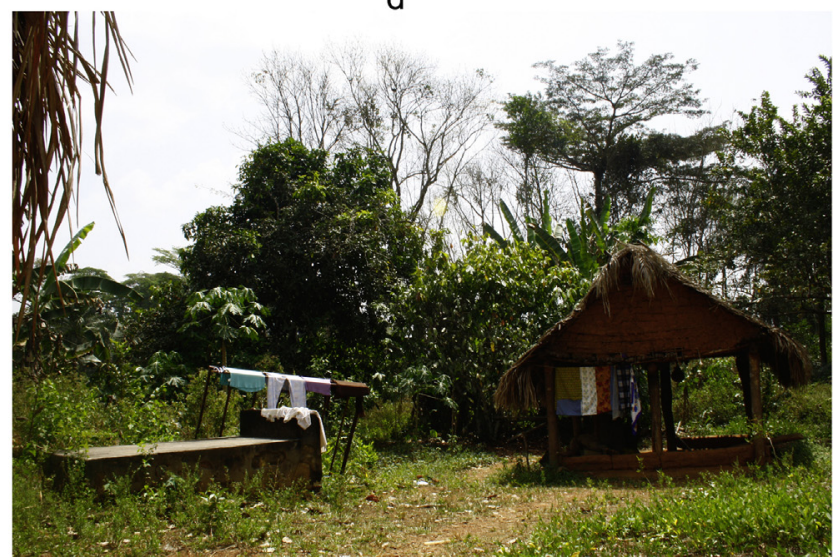

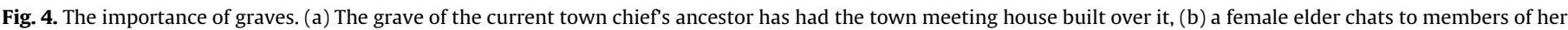

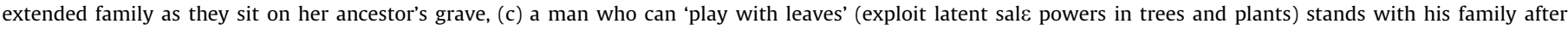

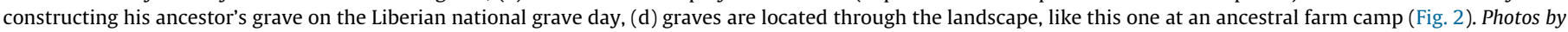
Victoria Frausin.

Montpellier panel of international agricultural experts recommends: "building on and sharing the expertise of African smallholder farmers," and the "scaling up and out of appropriate and effective technologies and processes" derived from these systems (The Montpellier Panel, 2013:4). Yet such pronouncements turn on the assumption that the physical-technical can be separated from the social aspects of 'indigenous knowledge', and simply scaled up as a solution to the 'problem' of sustainable development.

Our case study however has shown that the sustainability of a Loma traditional agro-ecosystem is bound up in a set of social and religious institutions and practices that we expressed as 'ancestral habitus'. These place spatial limits on the physicaltechnical optimisation or expansion of AfDE, a traditional agroecosystem exemplar. We demonstrated that AfDE food production is approximately twice as efficient than other systems available to the Loma. The Loma are well aware of how AfDE are produced yet they have neither optimised (i.e. cleared sacred forests) nor expanded their AfDE food production systemdespite productivity gains for labour expended, as we should expect them to if their motivation was to maximise production. It would be relatively easy to expand AfDE without heavier demands on labour by simply dumping in adjacent areas, slowly expanding coverage. Instead the Loma have kept dumping in the same areas for centuries, which has led to AfDE depths of up to $1.80 \mathrm{~m}$, far in excess of the $\sim 0.3 \mathrm{~m}$ necessary for enhanced agriculture.
Polanyi's formal economic rationality, which analysts often uncritically universalise, fails to account for the Loma nonexpansion/optimisation of this traditional agroecosystem. The rationalities through which the Loma people have traditionally managed natural resources and food production within their territory are closer to Polanyi's substantive rationality. The Loma inhabit an ontology which, through its ancestors, other supernatural agencies and initiation societies, shapes 'substantive' rationalities that inform everyday life and land tenure and land management decisions. We argue that these social 'limits' of the substantive economy underpin sustainability over time - the effective lack of interest on the part of the Loma in increasing productivity (i.e. growth) functions to limit possible expansion of the system, maintaining it in dynamic equilibrium. This is because traditionally, Loma individuals and groups get political power through ancestors and initiation societies rather than through increased resource flows. Hence, the sustainability or resilience of Loma society inheres in social institutions that have a limiting effect on growth. This, in effect, is what maintaining resilience or sustainability costs the system.

The fact that the living and the dead, the social and the religious are for the Loma one unity suggests that their society operates on different timescales to that of industrial societies. We infer that the timescales upon which Loma societal logic has traditionally operated are greater than the individualistic timescales of modern society in the west. This is because aspects of the present are contingent on the past actions of the ancestors, the lives of the 
a

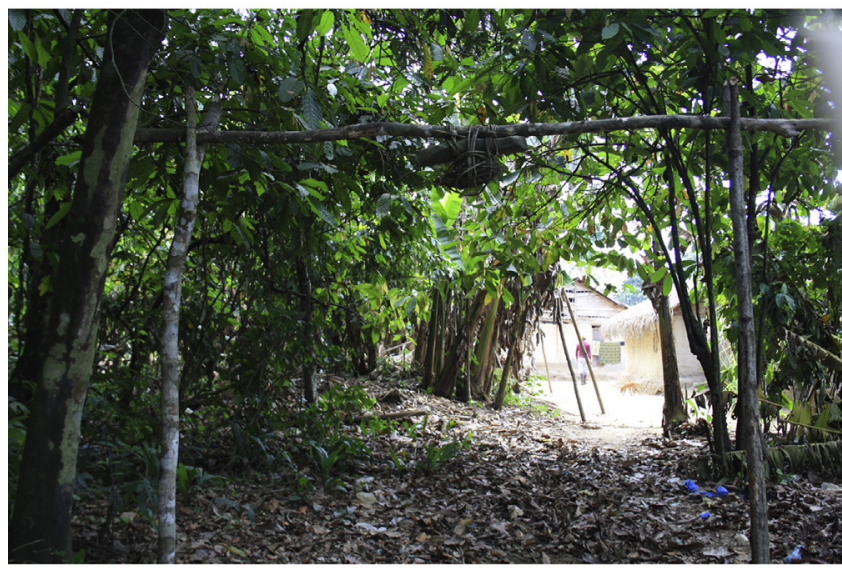

b

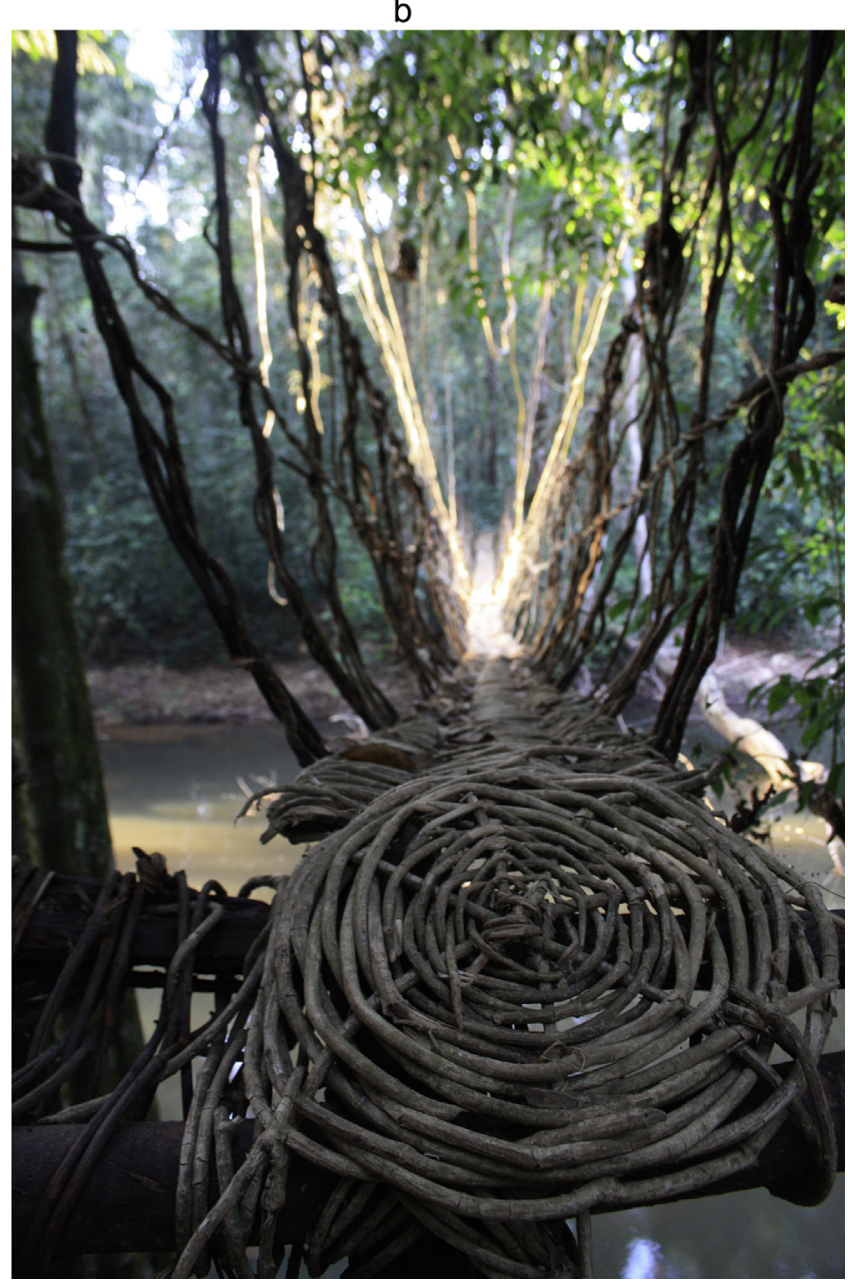

Fig. 5. Symbols of power in the Wenwuta landscape. Top image (a) A village entranceway features an object imbued with power to ward off evil. Bottom image (b) Bridges are woven from lianas by male initiation societies in secret (only the initiated can be present during construction). Circular symbols of initiation society power mark each end. Photos by Victoria Frausin.

living are subject to the will of past generations. Therefore, although the Loma social-ecological system may appear suboptimal when viewed from the perspective of the individual, it is optimal on some other much longer timescale. As with the discourse on sustainability in the west, for the Loma sustainability is a generational issue, but one that faces backwards to ancestors rather than forwards to future generations. This reverses the original Bruntland definition of sustainable development. For the Loma, sustainable development is development that meets the needs of the present without compromising the ability of past generations to meet their own needs. The fact that this approach to natural resource management appears to have resulted in a sustainable economy underlines the importance of a generational perspective in decision making when curtailing or redistributing surplus resource production. The Loma also teach us that sustainability is not simply a physio-technical issue; social and belief issues appear to be far more important in framing the behaviour of these systems.

\section{Acknowledgements}

We thank other members of the collaborative research programme from which the research reported in this article derives, including anthropologists James Fairhead and Melissa Leach at the University of Sussex, UK, Kojo Amanor at the University of Legon in Ghana, and Dominique Millimouno at Cabinet Universitaire de Recherches-Actions, Kissidougou, Republic of Guinea and soil scientists Johannes Lehmann and Dawit Solomon at Cornell University, Søren M. Kristiansen at Aarhus University, Denmark. Our joint work is cited. We thank Jeanette Carter of the University of Liberia for facilitating our research project and officials of the government of Liberia for granting permission to conduct research. We thank Woulay Narmah and Gayflor Kesselie for assistance in fieldwork, and Adam Manvell for kindly visiting Wenwuta to pick up survey data from Gayflor. We thank participants from Lancaster Environment Centre's Society \& Environment Work-in-Progress seminar where feedback was given on an earlier draft: Beth Brockett, Guy Crawford, Rebecca Ellis, Nigel Clark, Nils Markusson, Ben Neimark and Anne Toomey. We thank two anonymous reviewers for their comments which helped us to significantly improve the manuscript. Any errors of fact and judgement rest with the authors.

This article draws on research funded by the UK Economic and Social Research Council (ESRC RES-062-23-2310) through the grant "Anthropogenic dark earths in Africa?" to Sussex University, and the "Biochar" project of the ESRC STEPS (Social, Technological and Environmental Pathways to Sustainability) Centre, and we gratefully acknowledge this financial support.

\section{References}

Altieri, M., Nicholls, C., 2013. The adaptation and mitigation potential of traditional agriculture in a changing climate. Clim. Change 1-13.

Altieri, M.A. 2002. Agroecology: the science of natural resource management for poor farmers in marginal environments. Agric. Ecosyst. Environ. 93, 1-24.

Andriesse, W., Fresco, L.O., 1991. A characterization of rice-growing environments in West Africa. Agric. Ecosyst. Environ. 33, 377-395.

Appiah-Opoku, S., Hyma, B., 1999. Indigenous institutions and resource management in Ghana. Indig. Knowl. Dev. Monitor 7, 15-17

Arnold, J.E.M., Perez, M.R., 2001. Can non-timber forest products match tropical forest conservation and development objectives? Ecol. Econ. 39, 437-447.

Atran, S., Axelrod, R., Davis, R., 2007. Sacred barriers to conflict resolution. Science 317, 1039-1040.

Awuah-Nyamekye, S., Sarfo-Mensah, P., 2011. Ensuring equitable distribution of land in Ghana: spirituality or policy? A case study from the forest-savanna agroecological zone of Ghana. Int. Indig. Policy J. 2.

Berkes, F., 2008. Sacred Ecology. Routledge.

Berns, G.S., Bell, E., Capra, C.M., Prietula, M.J., Moore, S., Anderson, B., Ginges, J., Atran, S., 2012. The price of your soul: neural evidence for the non-utilitarian representation of sacred values. Philos. Trans. R. Soc. B: Biol. Sci. 367 $754-762$.

Berry, S., 1989. Social institutions and access to resources. Africa 59, 41-55.

Bledsoe, C., 1984. The political use of Sande ideology and symbolism. Am. Ethnol. $11,455-472$

Bloch, M., 2008. Why religion is nothing special but is central. Philos. Trans. R. Soc B: Biol. Sci. 363, 2055-2061.

Bohannan, P., 1955. Some principles of exchange and investment among the Tiv of Central Nigeria. Am. Anthropol. 57, 60-70. 
Bourdieu, P., 1977. Outline of a Theory of Practice. Cambridge University Press, Cambridge.

Brookfield, H., Padoch, C., 1994. Appreciating agrodiversity: a look at the dynamism and diversity of indigenous farming practices. Environment 36, 6-21.

Brooks, G.E.J., 1989. Ecological perspectives on Mande population movements, commercial networks, and settlement patterns from the Atlantic Wet Phase (ca. 5500-2500 B.C.) to the present. Hist. Afr. 16, 23-40.

Byers, B., Cunliffe, R., Hudak, A., 2001. Linking the conservation of culture and nature: a case study of sacred forests in Zimbabwe. Hum. Ecol. 29, 187-218.

Calhoun, C.J., 1980. The authority of ancestors: a sociological reconsideration of Fortes's Tallensi in response to Fortes's critics. Man (n.s.) 15, 304-319.

Chouin, G., 2009. Forests of Power and Memory: An Archaeology of Sacred Groves in the Eguafo Polity, Southern Ghana (c. 500-1900 A.D.), Anthropology Syracuse University.

Cleveland, D., 2014. Balancing on a Planet: The Future of Food and Agriculture University of California Press.

d'Azevedo, W.L., 1962. Some historical problems in the delineation of a central west atlantic region. Ann. N. Y. Acad. Sci. 96, 512-538, Discussion 574-580.

d'Azevedo, W.L., 1989. Tribe and chiefdom on the windward coast. Liber. Stud. J. 14, 90-116.

De Schutter, O., 2011, March. Agroecology and the Right to Food. Report Presented at the 16th Session of the United Nations Human Rights Council [A/HRC/16/49], http://www.srfood.org/images/stories/pdf/officialreports/ 20110308_a-hrc-16-49_agroecology_en.pdf [accessed 07.10.14]

Duvall, C.S., 2011. Biocomplexity from the ground up: vegetation patterns in a West African savanna landscape. Ann. Assoc. Am. Geogr. 101, 497-522.

Ellis, S., 2007. The Mask of Anarchy: The Destruction of Liberia And the Religious Dimension of an African Civil War. University Press, New York.

Fahey, R.P., 1971. The poro as a system of judicial administration in Northwestern Liberia: its inttacland and interclan functions. Afr. Law Stud. 4, 1-25.

Fairhead, J., Geysbeek, T., Holsoe, S.E., Leach, M., 2003. African-American Exploration in West Africa: Four Nineteenth-Century Diaries. Indiana University Press, Bloomington, IN

Fairhead, J., Leach, M., 1996. Misreading the African Landscape: Society and Ecology in a Forest-Savanna Mosaic. Cambridge University Press, Cambridge.

Fairhead, J., Leach, M., 2005. The centrality of the social in African farming. IDS Bull. 36, 86-90.

Fairhead, J., Scoones, I., 2005. Local knowledge and the social shaping of soil investments: critical perspectives on the assessment of soil degradation in Africa. Land Use Policy 22, 33-41.

Fanthorpe, R., Maconachie, R., 2010. Beyond the 'Crisis of Youth'? Mining, farming, and civil society in post-war Sierra Leone. Afr. Aff. 109, 251-272.

Foley, J.A., Ramankutty, N., Brauman, K.A., Cassidy, E.S., Gerber, J.S., Johnston, M., Mueller, N.D., O/'Connell, C., Ray, D.K., West, P.C., Balzer, C., Bennett, E.M., Carpenter, S.R., Hill, J., Monfreda, C., Polasky, S., Rockstrom, J., Sheehan, J., Siebert, S., Tilman, D., Zaks, D.P.M., 2011. Solutions for a cultivated planet. Nature 478, 337-342.

Fontein, J., 2011. Graves, ruins, and belonging: towards an anthropology of proximity. J. R. Anthropol. Inst. 17, 706-727.

Fortes, M., 1965. Some reflections on Ancestor Worship in Africa. In: Dieterlen, M.F.a.G. (Ed.), African Systems of Thought. Oxford University Press for the International African Institute, London, pp. 122-142.

Fraser, J.A., Diabaté, M., Narmah, W., Beavogui, P., Guilavogui, K., de Foresta, H. Junqueira, A.B., n.d. Sacred Agroforests combine cultural, economic and conservation benefits in the Upper Guinea Forest, West Africa. Manuscript.

Fraser, J.A., Leach, M., Fairhead, J., 2014. Anthropogenic dark earths in the landscapes of Upper Guinea, West Africa: intentional or inevitable? Ann. Assoc. Am. Geogr. 1-17.

Frausin, V., Fraser, J., Narmah, W., Lahai, M., Winnebah, T.A., Fairhead, J., Leach, M., 2014. "God made the soil, but we made it fertile": gender, knowledge, and practice in the formation and use of African dark earths in liberia and Sierra Leone. Hum. Ecol. 1-16.

Fulton, R.M., 1972. The political structures and functions of poro in Kpelle society. Am. Anthropol. 74, 1218-1233.

Ginges, J., Atran, S., Medin, D., Shikaki, K., 2007. Sacred bounds on rational resolution of violent political conflict. Proc. Natl. Acad. Sci. U. S. A. 104, 7357-7360.

Glaser, B., 2007. Prehistorically modified soils of central Amazonia a model for sustainable agriculture in the twenty-first century. Philos. Trans. R. Soc. London: Ser. B 362, 187-196.

Glaser, B., Birk, J.J., 2012. State of the scientific knowledge on properties and genesis of Anthropogenic Dark Earths in Central Amazonia (terra preta de Indio) Geochim. Cosmochim. Acta 82, 39-51.

Glaser, B., Haumaier, L., Guggenberger, G., Zech, W., 2001. The 'terra preta' phenomenon: a model for sustainable agriculture in the humid tropics. Naturwissenschaften $88,37-41$.

Gliessman, S.R., 2007. Agroecology: The Ecology of Sustainable Food Systems. CRC Press.

Gudeman, S., 2001. The Anthropology of Economy: Community, Market and Culture. Blackwell, Oxford.

Hann, C., Hart, K., 2011. Economic Anthropology. Wiley.

Hobbs, P.R., Sayre, K., Gupta, R., 2008. The role of conservation agriculture in sustainable agriculture. Philos. Trans. R. Soc. B: Biol. Sci. 363, 543-555.

Hojberg, C., 2007. Resisting State Iconoclasm Among the Loma of Guinea. Carolina Academic Press, Durham, NC.

Honwana, A.M., de Boeck, F., 2005. Makers \& Breakers: Children \& Youth in Postcolonial Africa. Africa World Press.
Janson, M., 2013. Islam, Youth and Modernity in the Gambia: The Tablighi Jama'at. Cambridge University Press.

Kawa, N.C., 2008. Amazonian dark earth: a model of sustainable agriculture of the past and future? Int. J. Environ. Cult. Econ. Soc. Sustain. 4, 9-16.

Knörr, J., Filho, W.T., 2010. The powerful presence of the past: integration and conflict along the Upper Guinea Coast. Brill.

Kopytoff, I., 1971. Ancestors as elders. Africa 41, 129-142.

Kusters, K., Achdiawan, R., Belcher, B., Perez, M.R., 2006. Balancing development and conservation? An assessment of livelihood and environmental outcomes of nontimber forest product trade in Asia, Africa, and Latin America. Ecol. Soc. 11.

Leach, M., 1994. Rainforest Relations: Gender and Resource use among the Mende of Gola, Sierra Leone. Edinburgh University Press, Edinburgh.

Lebbie, A.R.G., Guries, R.P., 1995. Ethnobotanical value and conservation of sacred groves of the Kpaa Mende in Sierra Leone. Econ. Bot. 49, 297-308.

Leopold, R.S., 1991. Prescriptive Alliance and Ritual Collaboration in Loma Society. Indiana University, Bloomington.

Little, K.L., 1965. The political function of the Poro. Part 1. Africa 35, 349-365.

Little, K.L., 1966. The political function of the Poro. Part II. Africa 36, 62-72.

MacCormack, C., 1986. Dying as transformation to ancestorhood: the sherbro coast of Sierra Leone. In: Sich, D., Figge, H., Hinderling, P. (Eds.), Sterben und Tod Eine kulturvergleichende Analyse. Vieweg + Teubner Verlag, pp. 117-126.

Malaisse, F., Parent, G., 1982. Rodents of the Miombo woodland area: a nutritional and ecological approach. Ecol. Food Nutr. 211-216.

Marshall, C.A., Hawthorne, W.D., 2012. Regeneration ecology of the useful flora of the putu range rainforest, Liberia. Econ. Bot. 66, 398-412.

McCaskey, T.C., 1995. State and Society in Pre-colonial Ashanti. Cambridge University Press, Cambridge.

McGovern, M., 2012. Unmasking the State: Making Guinea Modern. University of Chicago Press.

Mouïnou, A., Centre, E.C.J.R., Union, E., Jones, A., 2013. Soil Atlas of Africa. Renouf Publishing Company Limited.

Mowo, J., Adimassu, Z., Catacutan, D., Tanui, J., Masuki, K., Lyamchai, C., 2013. The importance of local traditional institutions in the management of natural resources in the highlands of East Africa. Hum. Organ. 72, 154-163.

Murphy, W.P., Bledsoe, C.H., 1987. Kinship and territory in the history of a Kpelle Chiefdom (Liberia). In: Kopytoff, I. (Ed.), The African Frontier: The Reproduction of Traditional African Societies. Indiana Bloomington University Press, Bloomington

Newell, S., 2012. The Modernity Bluff: Crime, Consumption, and Citizenship in Côte D'Ivoire. University of Chicago Press.

Parrinder, E.G., 1961. West African Religions: A Atudy of the Beliefs and Practices of Akan, Ewe, Yoruba, Ibo and Kindred Peoples. The Epworth Press, London.

Paulme, D., 1954. Les Gens du Riz. Librairie Plon, Paris.

Perfecto, I., Vandermeer, J., Wright, A., 2009. Nature's matrix: linking agriculture, conservation and food sovereignty. Earthscan.

Peters, K., Richards, P., 2011. Rebellion and agrarian tensions in Sierra Leone, J. Agrar. Change 11, 377-395.

Polanyi, K., 1957. The economy as instituted process. In: Polanyi, K., Arensberg, C., Pearson, H. (Eds.), Trade and Market in the Early Empires: Economies in History and Theory. Free Press, Glencoe, IL, pp. 243-269.

Poorter, L., Bongers, F., Lemmens, R.H.M.J., 2004. West African forests: introduction. In: Poorter, L., Bongers, F., Kouame, F.N., Hawthorne, W.D. (Eds.), Biodiversity of West African Forests: An Ecological Atlas of Woody Plant Species. CABI Publishing, Wallingford, UK.

Richards, P., 1985. Indigenous Agricultural Revolution: Ecology and Food Production in West Africa. Hutchinson \& Co., London.

Richards, P., 1986. Coping with hunger: hazard and experiment in an African ricefarming system. Allen and Unwin, London.

Richards, P., 1993. Cultivation: knowledge or performance. In: Hobart, M. (Ed.), An Anthropological Critique of Development: The Growth of Ignorance. Routledge, London/New York, pp. 61-78.

Richards, P., 1996. Fighting for the Rainforest: War, Youth \& Resources in Sierra Leone. James Currey, Oxford.

Sahlins, M.D., 1972. Stone age economics. Aldine.

Sasaoka, M., Laumonier, Y., 2012. Suitability of local resource management practices based on supernatural enforcement mechanisms in the local social-cultural context. Ecol. Soc. 17

Schmidt, M., 2013. Amazonian Dark Earths: pathways to sustainable development in tropical rainforests? Bol. Mus. Para. Emílio Goeldi. Cienc. Hum. 8, 11-38.

Schmidt, M.J., Rapp Py-Daniel, A., de Paula Moraes, C., Valle, R.B.M., Caromano, C.F., Texeira, W.G., Barbosa, C.A. Fonseca, J.A., Magalhães, M.P. Silva do Carmo Santos, D., da Silva e Silva, R., Guapindaia, V.L., Moraes, B., Lima, H.P., Neves, E.G., Heckenberger, M.J., 2014. Dark earths and the human built landscape in Amazonia: a widespread pattern of anthrosol formation. J. Archaeol. Sci. 42, 152-165.

Sheridan, M.J., Nyamweru, C., 2008. African Sacred Groves: Ecological Dynamics and Social Change. James Currey Ltd., London.

Shipton, P.M.D., 2009. Mortgaging the Ancestors: Ideologies of Attachment in Africa. Yale University Press.

Solomon, D., Lehmann, J., Fraser, J.A., Leach, M., Amanor, K., Frausin, V., Kristiansen, S., Millimouno, D., Fairhead, J., n.d. Indigenous African soil enrichment as climate-smart sustainable agriculture alternative. Manuscript.

Sombroek, W., Ruivo, M., Fearnside, d.L., Glaser, P.M., Lehmann, B.J., 2003. Amazonian dark earths as carbon stores and sinks. In: Lehmann, J., Kern, D.C., Glaser, B., Woods, W.I. (Eds.), Amazonian Dark Earths: Origin, Properties, Management. Kluwer Press, Dordrecht, pp. 125-139. 
Sombroek, W.G., Kern, D., Rodrigues, T., Cravo, M., Cunha, d.S., Woods, T.J., Glaser, W.I.B., 2002. Terra Preta and Terra Mulata: pre-Columbian Amazon kitchen middens and agricultural fields, their sustainability and their replication. In: 17th World Congress of Soil Science, Bangkok, Thailand.

Steiner, C., Texeira, W.G., Zech, W., 2003. Slash and Char: an alternative to slash and burn practiced in the Amazon Basin. In: Glaser, B., Woods, W.I. (Eds.), Amazonian Dark Earth: Explorations in Space and Time. Springer-Verlag, Berlin.

The Montpellier Panel, 2013. Sustainable Intensification: A New Paradigm for African Agriculture http://ag4impact.org/publications/montpellier-panel-report2013/ [Accessed 19/02/2015]

Tittonell, P., 2014. Ecological intensification of agriculture - sustainable by nature. Curr. Opin. Environ. Sust. 8, 53-61.

Ubink, J.M., Quan, J.F., 2008. How to combine tradition and modernity? Regulating customary land management in Ghana. Land Use Policy 25, $198-213$. van Vliet, N., Mertz, O., Heinimann, A., Langanke, T., Pascual, U., Schmook, B., Adams, C., Schmidt-Vogt, D., Messerli, P., Leisz, S., Castella, J.-C., Jørgensen, L., BirchThomsen, T., Hett, C., Bech-Bruun, T., Ickowitz, A., Vu, K.C., Yasuyuki, K., Fox, J., Padoch, C., Dressler, W., Ziegler, A.D., 2012. Trends, drivers and impacts of changes in swidden cultivation in tropical forest-agriculture frontiers: a global assessment. Global Environ. Change 22, 418-429.

Vandermeer, J., 2011. The Ecology of Agroecosystems. Jones \& Bartlett Learning. von Heland, J., Folke, C., 2013. A social contract with the ancestors-culture and ecosystem services in southern Madagascar. Global Environ. Change, http:// dx.doi.org/10.1016/j.gloenvcha.2013.11.003.

Wadley, R., Colfer, C.P., 2004. Sacred forest, hunting, and conservation in West Kalimantan, Indonesia. Hum. Ecol. 32, 313-338.

WCED, 1987. Our Common Future. World Commission on Environment and Development Oxford University Press, Oxford.

Zetterström, K., 1980. Poro of the Yamein Mano, Liberia. Ethnol. Z. Zürich 1, 41-59. 